\title{
APPLICATION OF VARISTOR-POSISTOR STRUCTURE FOR PROTECTION FROM OVERVOLTAGES OF PHOTOVOLTAIC CELLS OF SOLAR ARRAYS
}

\author{
A.V. Ivanchenko*, A.S. Tonkoshkur, S.V. Mazurik \\ Oles Honchar Dnipro National University, Dnipro, Ukraine \\ *e-mail: IvanchenkoAV@ukr.net
}

The problems of reducing the cost of ensuring the safe operation of solar cells by using low-cost elements of solid-state electronics to protect against overvoltage photovoltaic cells of solar arrays are considered. The results of experimental studies of the use of a varistor-posistor structure based on a metal oxide varistor and PPTC fuses of the PolySwitch type being in thermal contact to prevent overvoltages in series connections of photovoltaic cells are presented. General schemes for using the considered solid-state structure to limit the indicated constant overvoltages are given and justified. The requirements to the parameters of this structure are determined and experimentally verified. It is shown that such a device makes it possible to limit the long-term constant overvoltages that occur in photovoltaic arrays at the level of photovoltaic cells in the case of their malfunction or shadowing, which can lead to fire hazard and other "abnormal" situations during the operation of solar electric energy sources.

Keywords: photovoltaic cell, varistor ceramics, posistor nanocomposite, PPTC fuse, voltage limiting device, current-voltage characteristic.

Received 09.09.2019; Received in revised form 10.10.2019; Accepted 15.10.2019

\section{Introduction}

Inhomogeneous dielectrics are widely used to create modern elements of functional electronics, such as varistors, PPTC fuses, semiconductor gas-sensitive sensors, etc. [1-4].

Hybrid structures based on these dielectrics possess a number of unique electrical properties. Such structures include a new combined two-layer system, one layer of which is varistor ceramics and the second layer is the nanocomposite used in the PPTC fuse of the PolySwitch technology; the layers are in thermal contact $[5,6]$.

The equivalent scheme of such combined structure is shown in Fig. 1a.

A varistor layer and a posistor layer are connected in series. When an input overvoltage is applied to such a structure, the current flowing through the varistor layer heats it. The heat dissipated by this varistor layer heats the posistor one and this leads to an increase in the resistance of the posistor layer.

As a result, there is a redistribution of the input overvoltage between the layers. This ensures voltage limitation at a given value on the varistor layer (output voltage) and, therefore, on the load, which is connected in parallel with the varistor layer (Fig. 1b). Thus, this device can provide protection of electrical circuits from constant overvoltages, which are one of the main problems in solving tasks of increasing the reliability of photovoltaic arrays in solar energy [7-9].

One of the well-known models of the occurrence of overvoltages in photovoltaic modules is considered in paper [10]. The photovoltaic module (solar panel) consists of seriesconnected photovoltaic cells, which are divided into several submodules [10-12]. Each such submodule is equipped with a bypass diode, which is connected in parallel with the submodule.

If one or several photovoltaic cells reduce the photocurrent generated by them (due to a malfunction or shadowing), then the bypass diode $\mathrm{D}$ provides an alternative current path from other submodules (Fig. 2). The voltage drop on the entire submodule coincides with the low voltage drop on the forward biased diode (about 0.3-1 V [10]), which corresponds to an almost short circuit of the considered submodule.

The lighted cells inside the submodule cannot transfer their generated photocurrents to an external electrical circuit because the serial connection is broken by a cell (or cells) with a reduced photocurrent. 


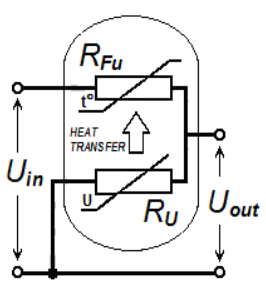

$a$

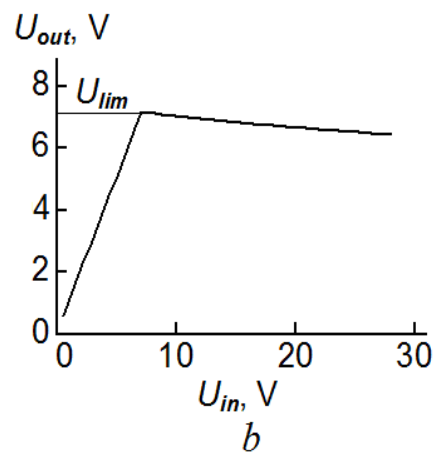

Fig. 1. Transient characteristic $U_{\text {out }}=f\left(U_{\text {in }}\right)$ and equivalent scheme of voltage limiting device based on varistor-posistor structure.

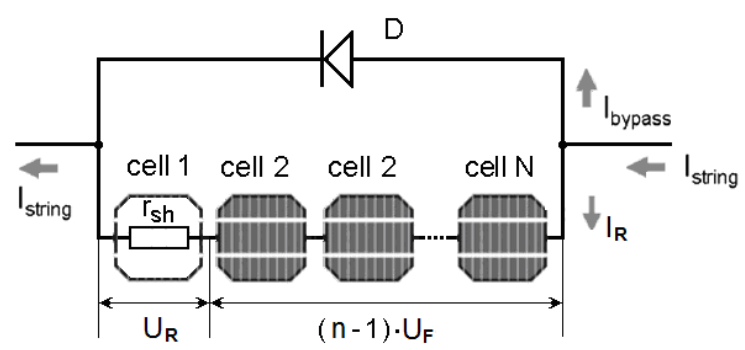

Fig. 2. Simplified presentation of a separate submodule of photovoltaic module. Cell 1 is a "bad" photovoltaic cell (has a reduced photocurrent).

$D$ is the bypass diode; $U_{F}$ and $U_{R}$ are voltage drops at the forward biased p-n junction of the lighted photovoltaic cell and the reverse biased p-n junction of the "bad" photovoltaic cell (Cell 1); $I_{\text {string }}, I_{\text {bypass }}$ and $I_{R}$ are the current coming from other submodules, the current through the bypass diode $\left(I_{\text {bypass }} \approx I_{\text {string }}\right)$ and the leakage current through the shunt resistance $\left(r_{s h}\right)$ of the "bad" photovoltaic cell.

A forward bias on the lighted photovoltaic cells shifts such a "bad" element in the reverse direction, and it works as a load with resistance $r_{s h}$ and not as a generator. Energy dissipation at the indicated load leads to an inhomogeneous heating of the module, in particular, to the appearance of local heating regions ("hot spots") in it. The number of photovoltaic cells in the submodule should be small in order to prevent the voltage on the "bad" cell $U_{R}$ from exceeding the breakdown voltage $U_{b}$ of its reverse biased p-n junction. If this is not done, the photovoltaic cell will heat up. High temperatures in local areas of photovoltaic cell can lead to the appearance of "hot spots". Thus, thermal breakdown of the p-n junction can occur as the cell temperature increases. In this case, the magnitude of the reverse voltage decreases with increasing current and a local thermal drift of the magnitude of the reverse voltage in time takes place. One-dimensional current channels are formed. This can lead to internal temperatures well above $400{ }^{\circ} \mathrm{C}$ and damage to the photovoltaic cells [4].

It should be noted that recently the creation of effective systems for protecting components of the solar arrays from electrical overvoltages, which lead to the occurrence of local overheating (including the formation of "hot spots"), has become increasingly important. There are methods to eliminate these overloads that occur at the level of separate photovoltaic cells and other parts of the photovoltaic module. Such methods include: the use of photovoltaic cells with low reverse breakdown voltages [8]; inclusion of additional elements (bypass diodes and active bypass switches) in the photovoltaic array $[8,9,13,14]$. 
However, these methods are not universal and have disadvantages. The use of photovoltaic cells with a low reverse breakdown voltage limits the power that is dissipated by heating their local areas. But this can be an effective method of preventing "hot spots" only when the magnitude of the indicated power is insufficient to damage the photovoltaic cells. Currently available simulation results and experimental data indicate that bypass diodes in the rows of photoelectric converters do not fully protect against the appearance of "hot spots". Bypass diodes are more effective for preventing "hot spots" with very short line lengths of photovoltaic cells, which is not used in the modern design of solar panels for economic reasons. Active bypass switches are an improvement over bypass diodes, but this requires more complex circuit solutions and expenses [8].

The development of manufacturing technology and the use of low-cost elements of solid-state electronics, in particular, resettable fuses of the PolySwitch type [4, 15-19] and low-voltage varistors $[1,20]$, indicates the prospects of their application for solving the problem under consideration of overvoltage protection of photovoltaic cells of solar arrays. The main advantages of such voltage limiting device are micro-miniature sizes, multiple switching (voltage limiting device do not lose operability after switching and do not require replacement) $[4,21]$ and, finally, the ability to pass significant (multi-ampere) currents through them. In this regard, actual tasks for advancing in this direction are the justification of general schemes for using the solid-state structure under consideration to limit the constant overvoltages in photovoltaic systems of solar arrays and determining the requirements for their parameters.

The results of experimental studies and analysis of the possibilities of using a varistor-posistor structure based on a metal oxide varistor and a PPTC fuse of the PolySwitch type being in thermal contact to prevent overvoltages in series connections of photovoltaic cells are presented in this paper.

\section{Physical fundamentals}

One of the most well-known methods of protection against high voltage of an electric circuit element is to install a voltage limiting devices in parallel to it $[1,20]$. In the case under consideration, this method allows us to propose an electrical circuit for protecting one photovoltaic cell or series-connected photovoltaic cells from overvoltages in the submodule of photovoltaic cells, which is shown in Fig. 3.

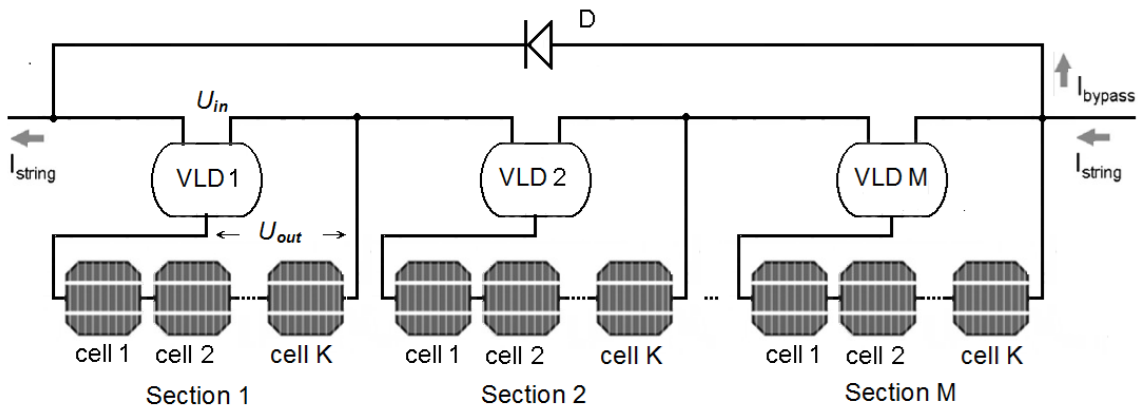

Fig. 3. Scheme of inclusion of a voltage limiter to protect photovoltaic cells.

$V L D$ 1, $V L D 2 \ldots V L D \mathrm{M}$ are voltage limiting devices. The remaining designations correspond to those adopted in Fig. 1 and 2.

Each section of several photovoltaic cells is connected to the output circuit of a separate voltage limiting device. Serial connection of input circuits of voltage limiting devices form a submodule of the photovoltaic module with a bypass diode connected in parallel to the submodule. Thus, a resettable fuse is connected between the separate 
sections of the photovoltaic cells and the varistor is connected in parallel to each section of the photovoltaic cells.

All photovoltaic cells are forward biased and have low resistance when the entire submodule is lightened and all its photovoltaic cells are identical. Current $I_{\text {string }}=I_{\text {subpanel }}$ flows through the submodule and the bypass diode $D$ is off (Fig. 4a). In this case, the following conditions are fulfilled, which ensure that the voltage limiting devices does not affect the functioning of the submodule in this (working) state.

- The voltage generated by a separate section of the photovoltaic cells $K \cdot U_{F}$ and applied to the varistor must be less than the classification voltage of the varistor $U_{C}$ (which must be less than the breakdown voltage of the reverse biased p-n junction of the section of the photovoltaic cells $U_{b}$ )

$$
K \cdot U_{F}<<U_{C}<U_{b}
$$

The varistor must be in a state with high resistance, and thus it does not affect the operation of the photovoltaic cells.

- The resistance of the PPTC fuse in the conductive state $R_{F u}$ (determined by the passport values: the minimum initial resistance or the maximum resistance after one hour after tripping at a given ambient temperature) must be many times less than the equivalent series resistance $\left(r_{s}\right)$ of the photovoltaic cells section

$$
R_{F u}<K \cdot r_{s} \text {. }
$$

- The tripping current $I_{t r i p}$, i.e. the minimum current flowing through the PPTC fuse at which the transition from a conducting to a non-conducting state occurs must be greater than the short circuit current of a separate photovoltaic cell $\left(I_{s c} \geq I_{\text {string }}=I_{\text {subpanel }}\right)$

$$
I_{s c} \geq I_{\text {trip }} \text {. }
$$
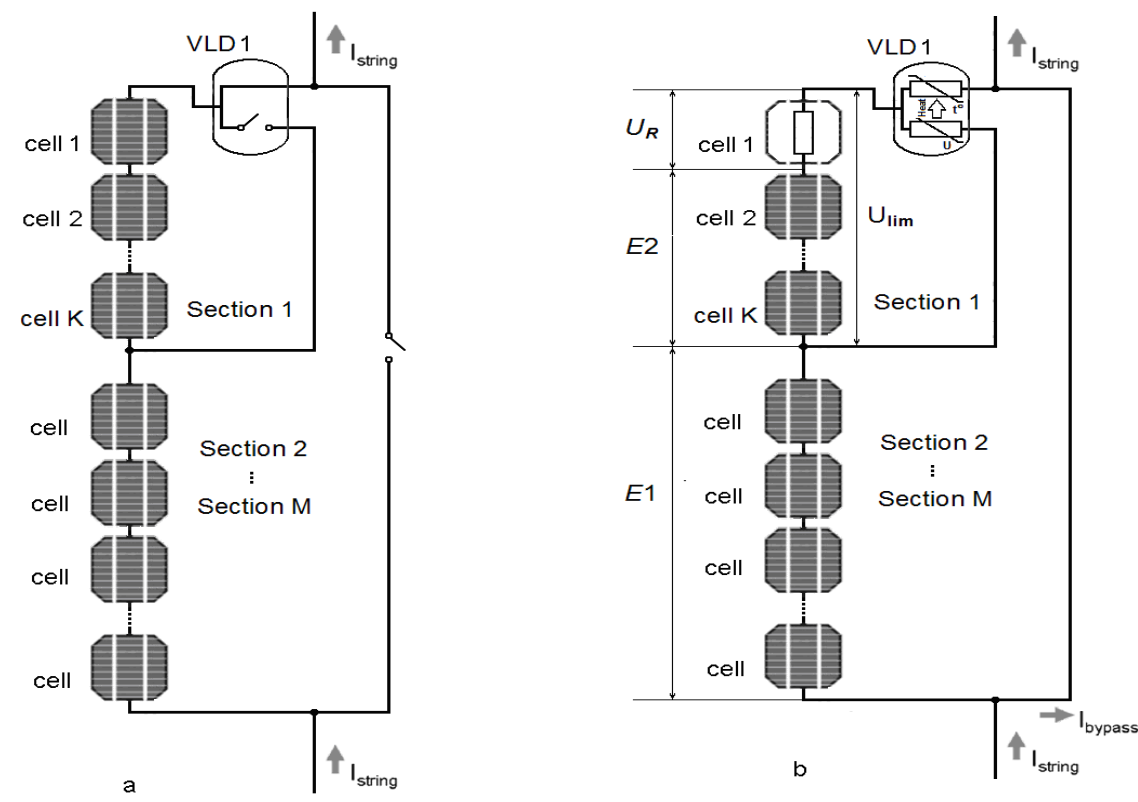

Fig. 4. Equivalent circuits illustrating the state of the voltage limiting device in the states of the submodule of the photovoltaic module during lighting and the absence of "bad" cells (a), the presence of one "bad" (malfunction or shaded) photovoltaic cell (b). 
In the presence of at least one "bad" photovoltaic cell with increased resistance, the current $I_{\text {string }}$ begins to flow through the bypass diode $D$ (diode is on), which short-circuits the submodule (Fig. 4b). As a result, a situation is realized when all the generated voltage by the lighted photovoltaic cells will shift the "bad" photovoltaic cell (or cells) in the reverse direction.

If the classification voltage of the varistor $U_{C}$ is less than the total voltage generated by the lightened sections of the photovoltaic cells located outside the Section 1 with a "bad" photovoltaic cells $E 1=K \cdot(M-1) \cdot U_{F}$ (Fig. 4b)

$$
U_{C}<E 1,
$$

then the varistor will heat up, transferring heat to the fuse. With increasing voltage limiting device temperature to $T_{\text {trip }}$, the fuse will increase its resistance. As a result, the generated voltage $E 1$ is redistributed so that part of it will drop on the high resistance of the PPTC fuse of the voltage limiting device, and the rest of the voltage will drop on Section $1 U_{\text {lim }} \approx U_{C}$.

It should be noted that in the considered state of the submodule the following physical restrictions must be fulfilled.

1. The voltage at the "bad" photovoltaic cells (which are protected from overheating) should not exceed the total breakdown voltage of these photovoltaic cells (Fig. 4b)

$$
k_{\text {uns }} \cdot U_{R}=U_{C}+E 2<k_{u n s} \cdot U_{b}
$$

where $k_{\text {uns }}$ and $E 2=\left(K-k_{\text {uns }}\right) \cdot U_{F}$ are the number of "bad" solar cells in Section 1 and the total voltage generated by all unshaded photovoltaic cells in this section; $U_{R}$ is the voltage drop at the reverse biased p-n junction of a "bad" photovoltaic cell $\left(U_{\text {lim }}=k_{\text {uns }} \cdot U_{R^{-}}-E 2\right)$;

2. The voltage applied to the varistor element in the absence of "bad" photovoltaic cells should be less than its classification voltage, i.e. $E 2=K_{\max } \cdot U_{F}<U_{C}$ (condition 1). $K_{\max }$ is the maximum possible number of series-connected photovoltaic cells in a section, i.e. $K_{\max }=\max (K)$.

From these restrictions, the equation can be obtained for the maximum number of series-connected photovoltaic cells in the group

$$
K_{\max }=\min \left[U_{C} / U_{F},\left(U_{b}-U_{C}\right) / U_{F}\right] .
$$

The maximum number of photovoltaic cells in the group protected by one voltage limiting device can be obtained from the equation (6). Taking into account that the voltage generated by one photovoltaic cell is $U_{F} \approx 0.56 \mathrm{~V}$ [22], the maximum number of photovoltaic cells in the group is 7,10 , and 7 when using varistor elements with classification voltages $U_{C}$ equal to 4,6 , and $8 \mathrm{~V}$, respectively. The highest voltage drop value on a separate "bad" photovoltaic cell occurs when it is shaded, and all other photovoltaic cells of sections are lightened.

\section{Experiment}

\subsection{Samples and research methods}

The samples of the voltage limiting device based on a two-layer structure of varistor ceramics and polymer nanocomposite with carbon filler were used in experiments.

The working element (the layer with a diameter of $13 \mathrm{~mm}$ and a thickness of $\sim 1 \mathrm{~mm}$ ) assembled from 18 commercial low-voltage chip varistors V3.5MLA0603NH (a dimensions $1.6 \times 0.8 \times 1 \mathrm{~mm}, U_{C}=3.7-7 \mathrm{~V}, \beta=30-50$ ) [23] connected in parallel was used 
as one of the layers, and the PPTC fuse of FRX110-60F type (the layer with a diameter of $13 \mathrm{~mm}$ and a thickness of $\sim 1 \mathrm{~mm}$, the resistance of the element in the conducting state is $0.38 \mathrm{Ohm} ; T_{\text {trip }}=125^{\circ} \mathrm{C}$ ) [24] was used as another layer. Thermal contact between the layers was provided by gluing with the use of silicon thermal conductive paste KPT- 8 [25].

The special experimental automated measuring complex [26] using the well-known method of a voltmeter-ammeter [27] was used to register light current-voltage characteristics. The test-bench allowed the use of natural solar radiation as a light source and it ensured the fulfillment of the standard spectral conditions AM1.5.

The study of the functioning of voltage limiting device in the submodule of the photovoltaic module was performed using the circuits shown in Fig. 4. The constant voltage source TEC14 was used as voltage E1 during their implementation in the experiment.

The main parameters that were measured for the circuit Fig. $4 \mathrm{~b}$ were the voltage drop at the output of voltage limiting device, on the reverse biased junction of protected "bad" photovoltaic cell (or cells), the currents flowing through the varistor element and the posistor element, the temperature of voltage limiting device, and their dependence on the voltage generated by the photovoltaic submodule.

\subsection{Experimental results}

\subsubsection{Characteristics of photovoltaic cells in full light mode}

The results of measurements of the light dependences of the generated current density $j$ and specific per unit surface area of electric power $p$ generated by a separate photovoltaic cell without and with the presence of a voltage limiting device on voltage $U_{F}$ are shown in Fig. 5.

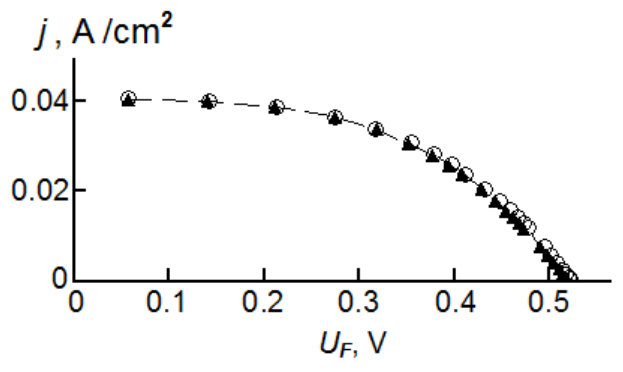

a

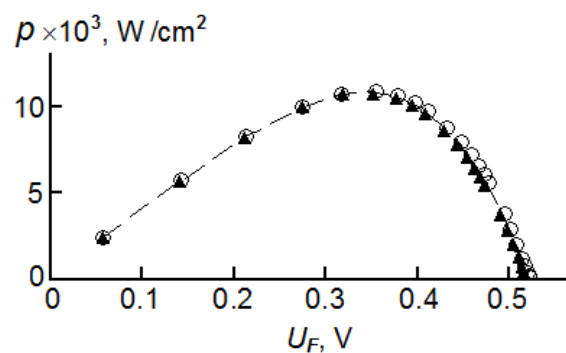

b

Fig. 5. Current-voltage and volt-watt characteristics of a separate photovoltaic cell without (circles) and with (filled triangles) connected voltage limiting device.

As can be seen, the presented current-voltage and volt-watt characteristics practically coincide, which indicates the fulfillment of the above conditions (1) - (3) of "transparency" of the considered voltage limiting device in the light mode (Fig. 4a).

\subsubsection{Voltage limitation of reverse biased photovoltaic cells}

In this situation, the photovoltaic cell (Cell 1) is "bad" (for example, shaded) and it is included in the submodule through separate voltage limiting device (i.e. $K=k_{\text {uns }}=1$ consequently $E 2=0, U_{\text {oul }}=U_{R}$ and $R_{\text {uns }}=r_{\text {sh }}$ ). The dependences of output voltage $U_{\text {out }}$ of the voltage limiting device which is applied directly to the reverse biased photovoltaic cell, the current density $j_{R}$ of this cell and the temperature $T$ of the voltage limiting device on the applied voltage $E 1$ generated by the remaining lightened photovoltaic cells of the submodule (Fig. 6) were obtained. 

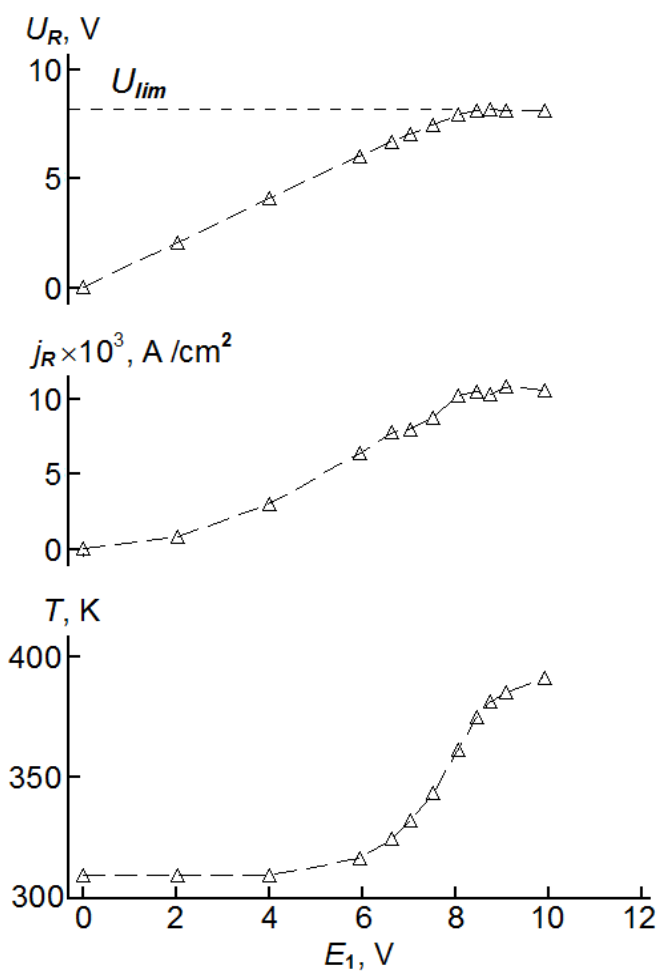

Fig. 6. Dependences of the voltage drop $U_{R}$ and current density $j_{R}$ of the "bad" reverse biased photovoltaic cell and temperature $T$ of the voltage limiting device on the applied limited input voltage E1.

The resulting dependencies reveal the following patterns.

1. The voltage drop at the "bad" photovoltaic cell corresponding to the output voltage of the voltage limiting device in the case under consideration $\left(U_{R}=U_{\text {out }}\right)$, for any $E 1$ (i.e. the number of lightened cells connected in series in the submodule with the bypass diode), does not exceed a certain value $U_{\text {lim }}$, relatively close to the classification voltage of a varistor element $U_{C}$.

2. The current through the reverse biased element is negligible. Its dependence on the input voltage $E 1$ is increasing with the achievement of a certain constant value.

3 . The beginning of the input voltage limiting region $E 1$ corresponds to reaching the temperature of the voltage limiting device close to the tripping temperature of the resettable fuse, which is equal to $398 \mathrm{~K}\left(125^{\circ} \mathrm{C}\right)$.

In accordance with the general scheme (Fig. 4b), when using one voltage limiting device for a group (section) of the photovoltaic cells, then the maximum overvoltage on a separate photovoltaic cell occurs if it is the only "bad" photovoltaic cell. In the analyzed situation, this corresponds to the conditions $K>1, k_{\text {uns }}=1, E 2=(K-1) U_{F}, U_{\text {out }}=U_{\text {lim }}=U_{R^{-}} E 2$ and $R_{\text {uns }}=r_{\text {sh }}$.

The dependences of the voltage drop on the reverse-biased photovoltaic cell $U_{R}$ and the output voltage of the voltage limiting device $U_{\text {lim }}$ on the number of lightened photovoltaic cells $(K-1)$ in the section with one common voltage limiting device are shown in Fig. 7. These data indicate that in the presence of lightened photovoltaic cells, the voltage drop across the reverse biased ("bad") junction of the photovoltaic cells increases by an amount equal to the voltage generated by these photovoltaic cells. The 
magnitude of the output voltage of the voltage limiting device $U_{\text {lim }}$ is practically unchanged and it is determined by the parameter of the varistor element of the voltage limiting device.

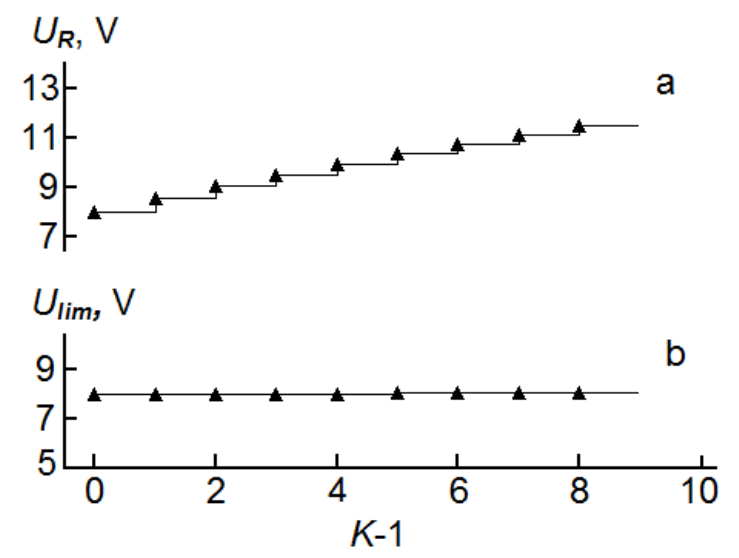

Fig. 7. Dependences of the maximum voltage on the "bad" reverse biased photovoltaic cell $U_{R}$ and of the varistor element of the voltage limiting device $U_{\text {lim }}$ on the number of lightened photovoltaic cells in the section. The mode corresponds to the situation when all photovoltaic cells except one are lightened and identical. ( $K$ is the total number of elements in the group. The classification voltage of the varistor element of the voltage limiting device is $U_{C}=6 \mathrm{~V}$.

As can be seen, the obtained experimental data are in accordance with the previously formulated physical concepts.

\section{Conclusions}

The results of the study of the electrical characteristics of the structure based on layers of varistor ceramics and a polymer PPTC nanocomposite being in thermal contact suggest that such a device has certain unique functional capabilities for realizing protection against DC overvoltages.

In principle, such a device makes it possible to limit the long-term constant overvoltages that occur in photovoltaic arrays at the level of photovoltaic cells in the case of their malfunction or shadowing, which can lead to an increase in electrical resistance and a loss in the ability to generate electrical power, and, as a result, to the occurrence of fire hazardous "abnormal" situations in the operation of solar sources of electrical energy.

However, it should be noted that when implementing such a solution in photovoltaic arrays, there are some difficulties. In particular, this is the lack of commercial production of disk-type varistor elements with a low classification voltage $(4-8 \mathrm{~V})$, which are suitable for use as a "heater" for such a voltage limiter.

\section{References}

1. Gupta, T.K. Application of zinc oxide varistors / T.K. Gupta // Journal of the American Ceramic Society. - 1990. - Vol. 73, No. 7. - P. 1817 - 1840.

2. Buchanan, R.C. Ceramic materials for electronics / R.C. Buchanan // CRC press. - 2004. - Vol. 68. - 684 p.

3. Gretzke, W. Use of PolySwitch PPTC protection in automotive applications / W. Gretzke // 42 V-PowerNets / eds. H. Wallentowitz, C. Amsel. - Berlin, Heidelberg: Springer, 2003. - P. $75-88$. 
4. Gavrikov, V. Samovosstanavlivayuschiesya PTC_predohraniteli dlya zaschiti ot tokovyh peregruzok / V. Gavrikov // Novosti Elektroniki. - 2014. - № 12. - P. 11 - 15.

5. Patent 7660096 B2 USA. Circuit protection device having thermally coupled MOV overvoltage element and PPTC overcurrent element / B. Golubovic, P.N. Becker, R.P. Moore. -9.02 .10 .

6. Tonkoshkur, A.S. Electrical properties of structures based on varistor ceramics and polymer nanocomposites with carbon filler / A.S. Tonkoshkur, A.V. Ivanchenko // Journal of Advanced Dielectrics. - 2019 - Vol. 9, No. 3. - P. 1950023-1 - 1950023-6.

7. Köntges, M. Review of failures of photovoltaic modules / M. Köntges, S. Kurtz, C. Packard, U. Jahn, K.A. Berger, K. Kato, T. Friesen, H. Liu, M. Van Iseghem // IEA PVPS Task 13. - 2014. $-132 \mathrm{p}$.

8. Kim, K.A. Reexamination of photovoltaic hot spotting to show inadequacy of the bypass diode / K.A. Kim, P.T. Krein // IEEE Journal of Photovoltaics. - 2015. - Vol. 5, No. 5.- P. 1435 - 1441.

9. Tonkoshkur, A.S. Problemy nadijnosti fotoelektrychnykh komponentiv sonjachnyh batarej/ A.S. Tonkoshkur, L.V. Nakashidze // Vidnovljuvana Enerhetyka. 2018. - № 3. - P.21 - 31 .

10. Daliento, S. A modified bypass circuit for improved hot spot reliability of solar panels subject to partial shading / S. Daliento, F. Di Napoli, P. Guerriero, V. d'Alessandro // Solar Energy. - 2016. Vol. 134. - P. 211 - 218.

11. Silvestre, S. Study of bypass diodes configuration on PV modules / S. Silvestre, A. Boronat, A. Chouder // Applied Energy. - 2009. - Vol. 86, No. 9. - P. 1632 - 1640.

12. Guerriero, $\mathbf{P}$. Accurate maximum power tracking in photovoltaic systems affected by partial shading/ P. Guerriero, F. Di Napoli, V. d'Alessandro, S. Daliento / International Journal of Photoenergy. - 2015. - Article ID 824832 (10 pages).

13. Acciari, G. Higher PV module efficiency by a novel CBS bypass / G. Acciari, D. Graci, A. L. Scala // IEEE transactions on power electronics. - 2010. - Vol. 26, No. 5. - P. $1333-1336$.

14. D'Alessandro, V. A simple bipolar transistor-based bypass approach for photovoltaic modules / V. D'Alessandro, P. Guerriero, S. Daliento // IEEE Journal of Photovoltaics. - 2014. - Vol. 4, No. 1. - P. 405 - 413.

15. Tonkoshkur, A. S. Primenenie samovosstanavlivayuschihsya elementov dlya elektricheskoj zashchity solnechnykh batarej / A.S. Tonkoshkur, A.V. Ivanchenko, L.V. Nakashidze, S.V. Mazurik // Tekhnologiya i Konstruirovanie v Elektronnoi Apparature. - 2018. - № 1. - P. 43 - 49.

16. Patent 6608470 USA. Overcharge protection device and methods for lithium based rechargeable batteries / J.W. Oglesbee, A.G. Burns. - 19.08.03.

17. Protecting rechargeable $\mathrm{Li}$-ion and Li-polymer batteries [Electronic resource]: $\quad$ Littelfuse, Inc. $\quad$ - 2018.- Mode access: http://www.littelfuse.com/ /media/electronics/ application_notes/littelfuse_protecting_rechargeable_li_ion_and_li_polymer_batteri es_in_consumer_portable_electronics_application_note.pdf.pdf

18. Ivanchenko, A.V. Application of "PolySwitch" fuses for the limitation of current overload sinphotovoltaic systems of solarar rays / A.V. Ivanchenko, A.S. Tonkoshkur, S.V. Mazurik // Journal of Physics and Electronics.- 2018. - Vol. 26(1). - P. $77-82$.

19. Brice, C.W. Review of technologies for current-limiting low-voltage circuit breakers / C.W. Brice, R.A. Dougal, J.L. Hudgins // IEEE Transactions on Industry Applications. - 1996. - Vol. 32. - No. 5. - P. 1005 - 1010. 
20. Standler, R.B. Protection of Electronic Circuits from Overvoltages / R.B. Standler. - Dover Publications INC. Mineola.-New York, 2002. - 464 p.

21. Kaminskaya, T.P. Samovosstanavlivayuschiesya predohraniteli dlya avtomobilnoi elektroniki / T.P. Kaminskaya, K.I. Domkin // Elektronnye komponenty. 2008. - № 5. - P. 80 - 82.

22. Koval', O.S. Opredelenie parametrov solnechnogo elementa iz ego svetovoj vol't-ampernoj harakteristiki / O.S. Koval', M.S. Tivanov // Vestnik BGU. - 2012. - Ser. 1. - № 2. - P. $39-44$.

23. Metal-Oxide Varistors (MOVs) Surface Mount Multilayer Varistors (MLVs) > MLA Series: [Electronic resourse]: Littelfuse, Inc. - Mode access: https://m.littelfuse.com/ /media/electronics/datasheets/varistors/littelfuse_varistor_mla_d atasheet.pdf.pdf

24. Fuzetec: Radial Leaded PTC Resettable Fuse: FRX Series: [Electronic resourse]: Fuzetec Technology Co., LTD. - Mode access: http://www.fuzetec.com/upload/download/App\%20FRX\%20Series\%20[Ver.6].pdf

25. Teploprovodnost' termopast, sravnenie termopast po teploprovodnosti i vjazkosti. [Electronic resourse]: Thermalinfo.ru. - Mode access: http://thermalinfo.ru/svojstva-materialov/materialy-raznye/teploprovodnost-termopastsravnenie-termopast-po-teploprovodnosti-i-vyazkost

26. Tonkoshkur, A.S. Zahist sonjachnih batarej vid elektrichnih perevantazhen': monografija / A.S. Tonkoshkur, A.V. Ivanchenko, L.V. Nakashidze, S.V. Mazurik; za zag. red. A.S. Tonkoshkura. - Dnipro: TOV „AKTSENT PP”, 2018. - 113 p.

27. Koltun, M.M. Optika i metrologija solnechnykh elementov / M.M. Koltun. Moscow: Nauka, 1985. -280 p.

28. Tonkoshkur, A.S. Modelirovaniye degradacii metalloksidnyh varistornyh jelementov zashhity jelektricheskih cepej: monografija / A.S. Tonkoshkur, A.V. Ivanchenko. - Dnipro: TOV „AKTSENT PP”, 2019. - 157 p. 